\title{
INCENDIOS FORESTAIS EN GALICIA E PORTUGAL*
}

Francisco Díaz-Fierros Viqueira Catedrático emérito da USC

DOI: 10.17075/unxl.2021.001

* Agradézolle ao profesor Luciano Lourenço as suxestións achegadas a este traballo. 



\section{INTRODUCIÓN}

No outono do 2018, a NASA estadounidense publicou unha gráfica sobre os incendios acaecidos no mundo no ano 2017 e a impresión que transmitía era que por todo o planeta había sinais de tal fenómeno. Imaxe que dalgún xeito estaba a dicirnos que os efectos do lume eran algo propio do planeta Terra e que practicamente ningún recuncho do globo estaba libre deles.

De todas as maneiras, se a representación se fixese con máis detalle e, sobre todo, se tivese en conta a proxección temporal dos incendios, xurdirían determinadas zonas do mundo nas que os lumes se concentrarían dun xeito máis relevante, como acontece, por exemplo, coas sabanas e, principalmente, cos territorios de clima mediterráneo. Este último tipo de clima sitúase entre os $30^{\circ}$ e $45^{\circ}$ tanto do hemisferio norte como do sur e nel atópanse territorios tales que California, a cunca do mar Mediterráneo, Chile, Sudáfrica e a Australia do suroeste, países onde os incendios dos seus espazos forestais non só están a acaparar as novas de actualidade dos xornais, senón que na súa propia historia foron deixando pegadas evidentes na cultura e na paisaxe. Esta sensibilidade dos climas mediterráneos aos incendios forestais derívase, de maneira fundamental, das características de inflamabilidade que lle transmiten ao combustible vexetal: uns outonos-invernos de temperaturas mornas e chuvias relativamente abundantes que favorecen o crecemento da biomasa, que despois, coa característica seca estival propia destes climas, se volve combustible con facilidade.

O clima mediterráneo euro-afro-asiático non só é o máis extenso do planeta, senón que tamén foi o primeiro que deu orixe a unha civilización agrícola e a unha cultura que foi a base da civilización occidental actual. Como sinala S. J. Pyne (1997), este mediterráneo é bastante máis que un clima, pois define «a place, a climate, a biota and a paradigm». O lume integrouse na súa propia historia e, para alén de ser a ferramenta fundamental coa que as prácticas agrarias e 
pastorais foron conquistando territorios cada vez máis abruptos, deu lugar, así mesmo, a unha vexetación adaptada á convivencia cos incendios e a un territorio no que os seus sinais ficaban claros e persistentes na paisaxe. Neste espazo, a fachada máis occidental, a que mira cara ao Atlántico, quedou cunhas características propias e diferenciadas do resto, pois as masas húmidas procedentes do océano fixeron que o período de outono-inverno acollese unhas precipitacións moito máis abondosas e dilatadas no tempo que noutros territorios da cunca mediterránea (Coimbra, $1082 \mathrm{~mm}$ anuais, fronte a, por exemplo, Roma, con $798 \mathrm{~mm}$, e Xerusalén, con $477 \mathrm{~mm}$ ), as cales, sumadas ás temperaturas mornas de todo o ano, daban orixe a unhas condicións óptimas para o crecemento vexetal, que son, sen dúbida, as máis importantes de toda a cunca.

Como consecuencia destas condicións tan favorables para o amoreamento do combustible, Galicia e Portugal, que son os dous países que miran ao Atlántico desde o Mediterráneo, son tamén os que padecen o maior número de incendios de todo este territorio (en especial desde o río Ulla ata o Texo), segundo amosa o mapa de Koutsias et al. (2015) para o período 2000-2010.

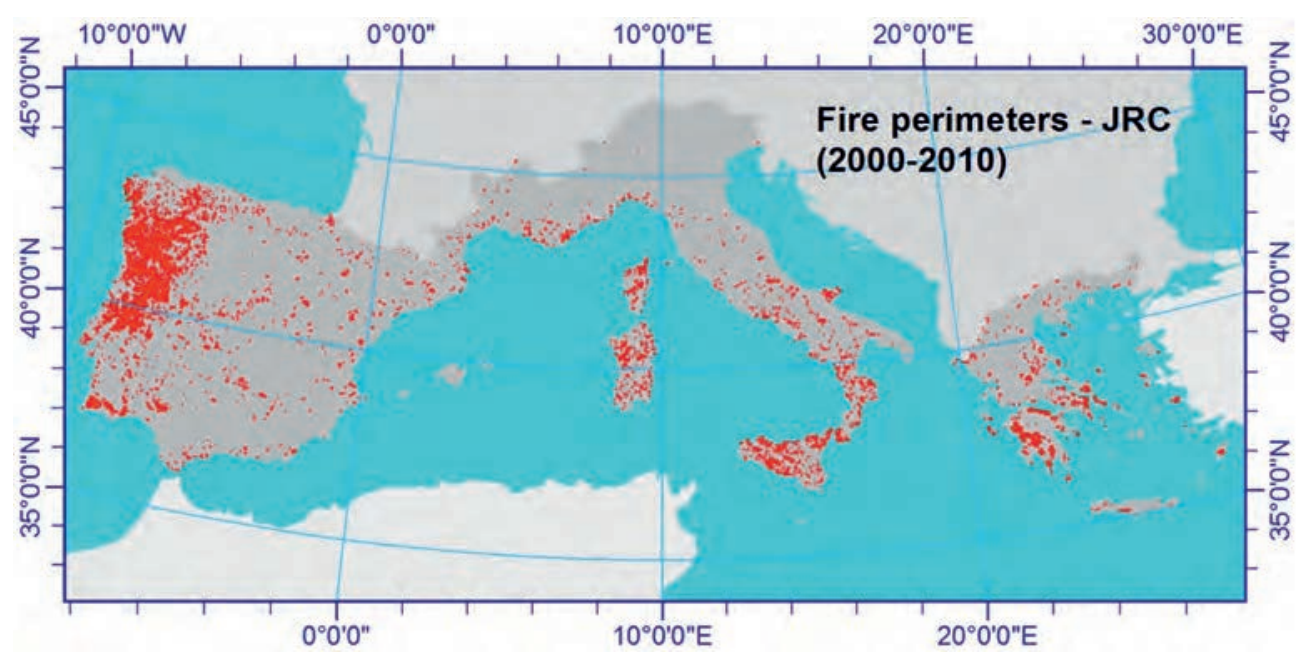

Figura 1. Incendios na cunca mediterránea (período 2000-2010) (Koutsias et al. 2015)

Tal singularidade do espazo atlántico-mediterráneo abondaría xa para considerar o interese e pertinencia de tentar describir unha historia común no relativo 
aos incendios forestais no que, por outra parte, ata o século XII foi un territorio compartido por un mesmo pobo e que, incluso despois desa data, seguiu a manter importantes similitudes xeográfico-sociais.

\section{PERÍODOS NA HISTORIA DO LUME}

Existen diferentes propostas para dividir a historia do uso do lume e dos incendios forestais na Terra. No caso que nos ocupa, e como marco temporal e conceptual deste traballo, consideraremos o esquema de Bowman et al. (2011), referido a toda a súa historia desde as orixes, hai centos de millóns de anos, ata a actualidade, e complementariamente a de Pausas e Keeley (2009), desde a modernidade, e a de Castellnou et al. (2007), desde 1950.

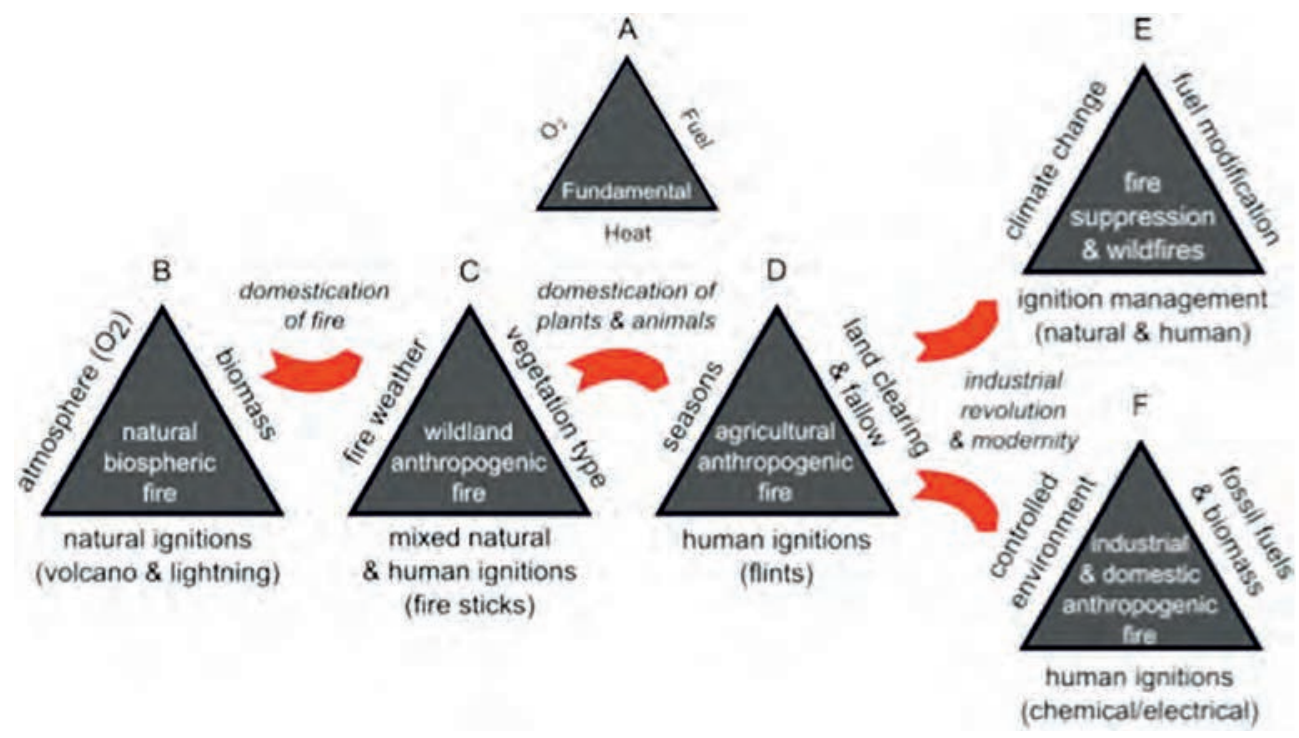

Figura 2. Fases píricas de Bowman et al. (2011)

De acordo cos primeiros autores, a orixe e posterior evolución dos lumes vai depender do que se define como «triángulo do lume» (esquema A na figura 2), no que interactúan tres factores: osíxeno, calor e combustible. Nos tempos pri- 
mixenios da historia da Terra, cunha atmosfera anóxica eran imposibles as combustións, polo que foi necesaria a chegada dos primeiros organismos fotosintetizadores (as algas e despois os vexetais) para que o osíxeno fixese a súa aparición. Posteriormente, coa colonización dos continentes emerxidos polos vexetais, apareceu o combustible como segundo elemento do triángulo, que en conxunción co osíxeno atmosférico é unha fonte de ignición natural, igual que podían ser os raios e os volcáns, os cales deron orixe xa aos primeiros incendios, os «incendios naturais biosféricos», tal como os define o esquema B da figura 2. Acontecía isto, de acordo cos últimos datos, no Silúrico, hai uns 400 millóns de anos.

A ubicua presenza de carbóns nos sedimentos desde esas datas amosa a importancia dos lumes naturais en canto factor importante da evolución dos ecosistemas; nalgúns casos - por exemplo, no do xénero Pinus e dalgunhas pradarías- actúan como axentes decisivos do seu éxito evolutivo e son responsables mesmo dalgúns dos seus caracteres máis salientables, que é o que sucede coa típica cortiza dos piñeiros.

A aparición dos primeiros homínidos en África hai 2,5 millóns de anos ${ }^{1}$ supuxo un cambio substancial no papel do lume na natureza, xa que estes novos primates comezaron a acoller, como unha das destrezas máis efectivas para a súa supervivencia, a do uso do lume. Existen evidencias desde hai 1,5 millóns de anos que amosan que o Homo erectus de África xa empezaba a ter un certo control sobre el e que, desde hai algo menos dun millón de anos ( 0,79 millóns), coas súas migracións xa era coñecido no Próximo Oriente, de onde posiblemente se expandiu cara a Europa (Pausas e Keeley 2009).

Durante o Paleolítico e o Mesolítico, cunha sociedade de cazadores-recolectores, o lume xa era utilizado para múltiples usos: clareo de matos e bosques co fin de facilitar os asentamentos, preparación dos alimentos, apertura de camiños, control de animais salvaxes prexudiciais, axuda para a caza, rexeneración de recursos alimenticios vexetais para homes e animais domésticos e mesmo como arma de guerra. Estaba a aparecer unha nova natureza na que a desaparición de

\footnotetext{
$1 \mathrm{Na}$ actualidade existen outras teorías que introducen certas novidades espazo-temporais na orixe de tales antecesores do home actual, pero neste traballo utilizaremos a que poderiamos cualificar como «teoría clásica».
} 
determinadas formacións vexetais polas queimas e a aparicións doutras máis adaptadas á convivencia co lume comezaban a definir unha paisaxe distinta. De acordo co esquema de Bowman et al. (figura 2), estaba a aparecer a fase pírica C de «lumes salvaxes antropoxénicos».

\section{OS PRIMEIROS AGRICULTORES DA IBERIA ATLÁNTICA}

O Neolítico define o paso de sociedades nómades de cazadores e recolectores a outras que, grazas ás técnicas agrarias, poden chegar a establecerse con máis ou menos persistencia nun determinado lugar. Estes pobos conseguiron, mediante as técnicas das rozas, estivadas ou arroteamentos, que aproveitaban a fertilidade que achegaban as cinzas dunha vexetación queimada previamente, que os cultivos de cereais puidesen manter unha pequena poboación asentada nun determinado lugar. No momento en que a fertilidade do solo se esgotaba polos sucesivos cultivos, había que practicar o mesmo sistema de queima e cultivo noutro lugar ata volver ao punto de partida, cando ao cabo de varios anos se recuperase a súa fertilidade, polo que estas prácticas tamén se denominaron de agricultura itinerante. Semella que o Neolítico naceu en Asia Menor hai uns 10000 anos e que desde alí se espallou en ondadas sucesivas cara ao resto dos pobos europeos, para chegar á Península Ibérica hai uns 6000 anos. A actividade agraria viuse acompañada, así mesmo, polo aproveitamento de pastos rexenerados polo lume ou de matos que, pola queima, daban orixe a brotes tenros para aproveitamento, nos dous casos, do gando ovino e vacún, polo que estas sociedades neolíticas deberían ser definidas realmente como de agricultores e pastores que, en calquera caso, tiñan sempre no lume a ferramenta básica de traballo. Esas actividades daban lugar, de xeito maioritario, a lumes controlados, que, de todas as maneiras, en situacións meteorolóxicas adversas derivarían en incendios de moi variables dimensións. Correspondería á fase pírica D: «lumes antropoxénicos agrícolas».

As técnicas que empregaban o lume para poñer en cultivo unha determinada zona de bosque foron descritas, a partir de experiencias en Dinamarca, por Iversen (1956) e foron denominadas «landnam» ou «ignicultura», ou, dun xeito máis popular, "cultivo mediante o lume» ou «cultivo en terra queimada», o cal, con diferentes variantes, chegou ata os nosos días como o modelo conceptual 
básico para explicar o aproveitamento do solo no Neolítico (Fábregas et al. 1997). O coñecemento actual da aplicación destas técnicas nun territorio determinado provén das análises de pole e doutros datos complementarios, tales que o estudo dos carbóns fósiles. Estes métodos permiten coñecer o impacto do lume sobre as formacións vexetais, nomeadamente sobre o bosque, e as diferentes etapas que seguen á súa destrución por el, así como identificar os diferentes cultivos e plantas acompañantes que presupoñen tamén o uso do fogo. En Galicia e Portugal existe na actualidade un número moi importante destas análises, que se sintetizarán seguindo as revisións de Fábregas et al. (1997) e Monteiro et al. (2006), con algunhas achegas puntuais de traballos máis recentes, como os de Carrión (2005) e Connor et al. (2012).

As primeiras evidencias de incendios no territorio galego-portugués son anteriores ao uso do lume para a agricultura, pois na serra da Estrela hai sinais claras de grandes áreas afectadas que deron orixe a importantes depósitos de carbóns sobre o 11400 ou 11300 BP (Connor et al. 2012) e nos montes do Buio e o Xistral, no contorno do $7500 \mathrm{BP}$, existen tamén testemuños fósiles de grandes incendios (Fábregas et al. 1997). Nestes casos habería que pensar que foron incendios descontrolados os que xeraron eses sinais paleobotánicos, porque a utilización do lume máis habitual naquela altura era só para pequenos clareos do bosque que facilitasen a caza e para tarefas domésticas. Nestas épocas había, sobre todo, un forte espallamento do bosque de quercíneas, que, en amplas zonas, cubría en masas mestas unha boa parte do país galego-portugués.

O pastoreo de gandos de ovino e vacún orixinou os seguintes sinais paleobotánicos de uso do lume. Este era aplicado na primavera para dar lugar despois a unha boa vexetación herbácea e mesmo, cando era mato o que se queimaba, para xerar gromos verdes comestibles. Na serra da Estrela, desde o $6400 \mathrm{BP}$, hai evidencias de incendios relacionados con esta economía, que rematou por asentarse nas serras portuguesas, dun xeito consolidado, polo 4000 BP. En Galicia, tal actividade está menos documentada, pero hai evidencias de comezos dela en Campo Lameiro sobre o $6300 \mathrm{BP}$ e de que se asenta xa dun xeito evidente sobre o 5500 ou 4000 (Carrión 2005) e se xeneraliza por todo o país no contorno do 4400 BP (Fábregas et al. 1997). Non é fácil calcular a extensión desta práctica do pastoreo, pero sería posible que na altura do 5000 ou 4000 BP unha boa parte das serras galegas e portuguesas estivesen xa deforestadas e cubertas por 
unha vexetación herbácea e que, como consecuencia das queimas sistemáticas a que eran sometidas, se orixinasen incendios descontrolados cando as condicións meteorolóxicas fosen adversas.

A práctica da ignicultura mediante rozas de ciclo longo ou curto (Boserup 1967) é probable que coincidise nos seus inicios coa economía pastoril, pois existen evidencias illadas de pole de cereal e plantas sinantrópicas en épocas tan adiantadas como o 6450 ou 6240 BP (Chan de Lamoso; Ramil-Rego et al. 1994), pero a súa consolidación non se deu ata o quinto milenio BP, no que se instala o sistema agropastoril e a propia agricultura se diversifica con outras especies, tales que a cebada, as leguminosas e o liño, que atendían a outras necesidades ademais das meramente alimentarias. Este cambio tamén se puido demostrar en xacementos arqueolóxicos e sedimentos do norte de Portugal (Fábregas et al. 1997). A súa xeneralización a todo o territorio galego-portugués deu orixe ao que Ramil-Rego (1992) denominou «estepa cultural», que situou no contorno temporal do $3700 \mathrm{BP}$.

A sedentarización definitiva das poboacións acaeceu no terceiro milenio BP coa cultura dos castros. $\mathrm{Na}$ volta destes asentamentos empezou a practicarse unha agricultura territorialmente estable grazas ás achegas en fertilizantes para o solo das dexeccións animais do gando doméstico que se ía incorporando á economía da familia ou do clan. Pero tamén o cultivo itinerante mediante as rozas continuou a ser un complemento indispensable que non só non se abandonou, senón que mesmo medrou e continuou co seu proceso deforestador, que nestas alturas estaba a espallar, en sucesión do bosque, un queirogal de Erica e Calluna que ademais comezaba a incluír, como especies pioneiras, leguminosas tales que Ulex.

No período romano e altomedieval, eses testemuños derivados das análises do pole e dos carbóns seguen a ser as referencias fundamentais dos efectos do lume, pois os documentos escritos que tratan destes temas son aínda moi escasos. Nos estudos citados da charca da Candieira e de Campo Lameiro apréciase un incremento importante da presión agropastoril, que leva practicamente á desaparición do bosque de Quercus e á súa substitución por queirogal de Erica, acompañado de leguminosas como Cistus ou Ulex, que son uns moi ben coñecidos colonizadores das terras queimadas e que mesmo chegan a desprazar as plantas herbáceas, que pasan a ser colonizadores secundarios do territorio. 


\begin{tabular}{|c|c|c|c|c|c|c|c|c|c|c|c|}
\hline Años B.P. & 8.000 & 7.500 & 7.000 & 6.500 & 6.000 & 5.500 & 5.000 & 4.500 & 4.000 & 3.500 & 3.000 \\
\hline Actividad Deforestadora & $\bullet$ & $\bullet \bullet$ & $\bullet$ & $\bullet$ & $\bullet$ & $\bullet$ & $\bullet \bullet$ & $\bullet$ & $\bullet$ & $\bullet$ & 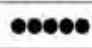 \\
\hline \multicolumn{12}{|l|}{ RESTOS VEGETALES } \\
\hline Recolección de plantis & $\bullet$ & $\bullet$ & 0 & 0 & 0 & $\bullet$ & $\bullet$ & $\bullet$ & $\bullet$ & ๑е॰ & $\bullet \bullet \bullet \bullet$ \\
\hline Polen de cereal y ruderales & & & & & & $\bullet$ & $\bullet$ & $\bullet$ & $\bullet$ & $\bullet$ & $\bullet \bullet$ \\
\hline Macrorrestos cultivos & & & & & & $\bullet$ & $\bullet$ & $\bullet$ & $\bullet \bullet$ & $\bullet \bullet$ & $\bullet \bullet \bullet \bullet \bullet$ \\
\hline \multicolumn{12}{|l|}{ RESTOS VEGETAIES } \\
\hline Animales domesticados & & & & & & 0 & $\bullet$ & $\bullet \bullet \bullet$ & $\bullet$ & $\bullet \bullet \bullet$ & $\bullet \bullet \bullet \bullet \bullet$ \\
\hline Caza & oo & $\infty$ & $0 \bullet$ & $\infty$ & Do & 0 & $\bullet$ & $\bullet$ & $\bullet$ & $\bullet$ & $\bullet$ \\
\hline Pesca y marisqueo & & & $\bullet$ & 0 & 0 & 0 & $\bullet$ & $\bullet \bullet$ & $\bullet$ & $\bullet$ & $\bullet \bullet \bullet \bullet \bullet$ \\
\hline TUMULOS & & & & & - & $\bullet \bullet$ & $\bullet$ & $\bullet \bullet$ & $\bullet \bullet$ & $\bullet$ & \\
\hline
\end{tabular}

Figura 3. Actividades relacionadas coa agricultura no Neolítico galego (Fábregas et al. 1997)

Como novidade importante en relación coas especies utilizadas nesta época teriamos o caso do castiñeiro, que, aínda que era coñecido de épocas anteriores, foi coa romanización cando iniciou o seu espallamento polo país galego-portugués en solos de non moi mala calidade, ao abrigo dos ventos e non moi afastados dos asentamentos de poboación. O centeo, coñecido tamén desde había moito tempo pero non utilizado como alimento, quizais pola cor escura da súa fariña, foi introducido e difundido polos pobos xermánicos, que estaban moi afeitos ao seu uso. $\mathrm{O}$ incremento da poboación e a boa adaptación do centeo aos solos máis pobres - por exemplo, os montesíos que sufriran xa varias queimasfixeron que fose adoptado sen moitos problemas como o cereal de elección para a ignicultura, segundo amosan con claridade os diagramas de pole da serra da Estrela.

Neste período, as queimas descontroladas do monte comezaban a ser moi frecuentes, de tal xeito que nun documento tan antigo como é o Fuero Juzgo (ano 634) se recollen as penas que debían aplicarse para aqueles que queimasen os montes intencionadamente ou por descoido, a cal é unha das primeiras referencias escritas relativas ao problema dos incendios forestais na Península Ibérica. 
LIBRO VIIL. TITVLO II.

dio. E si el sennor non quisiere fazer emienda por el siervo, dé el siervo '́ que lo descabecen.

II. De los omons que quemats monte.

$S_{i}$ algun omne enciende monte aieno , $\delta$ arbores = de qual maibera quier, préndalo $e l$ iuez, é fagal dar $\mathrm{C}$. azotes , é faga emienda de lo que quermó, cuemo asmaren omnes buenos $\mathrm{E}$ si el siervo lo fizo sin voluntad de so sennor, reciba C. é L. azotes, hy el sennor faga emienda por $\mathrm{e}$, si quisiere; é si non quisiere, hy el danno fuere dos tanto, 6 tres tanto que el siervo non vale, dé el siervo por el danno, é cea quito.
III. Do los que van s carrors, ef fios zen fuege.

Quien anda por camino", si " quiere fazer fuego en algun campo por cover ${ }^{6}$ de comer, 6 por se calentar, 6 por otra cosa, guśrdese que el firego non vaya mes adelavere que fage nemiga? ?. E.si se prendiere en restrojo " 6 en peia seca, mátelo", que non cresca 10 mas $\mathrm{E}$ si por ventura el fuega cresciene " mas, é quernare mies ", 6 era, $\delta$ vinoa, $\delta$ casa, $\delta$ vergel, $\delta$ atra cosa, aquel que lo encendio, porque se non guardó, peche tanto quanto valia "s la cosa que quemb.

Figura 4. Fragmento do Fuero Juzgo (na versión da Real Academia Española do ano 1815) no que trata das penas para as persoas que queiman os montes

Normas semellantes que penalizan os que, activa ou pasivamente, desencadean incendios son recollidas en posteriores códigos, como o de Afonso X de 1253 e outros de tipo local, tales que o Foro de Santiago de 1252, que ditaba: "[Q]ue nenguen faga fuego para quemar los montes, et a los que fallaren faciendo, quel echen dentro» (Guitián L 1999).

Existen evidencias abondas de que desde o século VII ata o XIII houbo un período de crecemento da poboación que levou tamén a un espallamento das prácticas agrarias: as terras máis aptas para o cultivo foron aproveitadas case na súa totalidade e incluso resultou preciso recorrer ao monte como fonte de fertilidade delas, coas cortas periódicas de mato, e, así mesmo, acudir ás cada vez máis necesarias rozas de terreos que había que poñer temporalmente en cultivo (Villares 1980, Ferreira 2008). É posible que se tratase dun momento en que os incendios descontrolados tiveron unha renovada incidencia. O bosque retrocedeu neste período dun xeito moi evidente, ao que seguiu, en paralelo, unha forte expansión do mato (Martínez-Cortizas e Costa-Casais 2016). Esta foi a época que concluíu coa independencia política de Portugal.

Eses séculos de bonanza deron paso, a partir do século XIV, a un período de crise no que os recursos comezaron a rarear e as epidemias, entre elas a peste, fixeron a súa aparición. Tamén as guerras completaron o negro panorama: loitas 
civís en Portugal e Galicia, así como as fronteirizas contra mouros e casteláns, viñeron sumarse ás calamidades anteriores, de tal xeito que a poboación deixou de crecer e mesmo, en moitas zonas, retrocedeu. A partir de mediados do século XV sentíronse os primeiros sinais de recuperación: novos cultivos e novos xeitos de organizar o traballo agrícola, con rotacións que permitían o mantemento da fertilidade nas terras de labradío, e un espallamento da gandaría transhumante, todo o cal fixo posible que de novo a poboación empezase a aumentar. Estaban a darse os primeiros pasos cara á Idade Moderna.

\section{A IDADE MODERNA}

O fenómeno do urbanismo representou un feito moi característico desta época, xa que nela foi cando comezou a creación das principais cidades europeas. De todos os modos, na área galaico-portuguesa que nos ocupa tratouse dun proceso dunha certa debilidade, pois, agás no caso de Lisboa, que acadou os 100000 habitantes nos albores do XVI, o resto das cidades (Santiago, Pontevedra, Braga, Porto, Coimbra etc.) non chegaban, pola mesma altura, aos 10000 habitantes. De calquera forma, esta debilidade non impediu que se constituísen en focos dunha demanda importante de novos materiais, como o ferro e o vidro, que tiñan no carbón vexetal un produto imprescindible para a súa elaboración.

Os procesos de fabricación dese recurso, que eran xa coñecidos e practicados desde había varios séculos, acadaron un espallamento especial neste período, que só foi interrompido pola aparición e uso do carbón mineral nas primeiras décadas do XIX. Os carboeiros que proliferaron no contorno dos centros de demanda (cidades, ferrarías e obradoiros de vidro, entre outros) xeraron unha importante práctica deforestadora pola cantidade de madeira que precisaban e ademais foron orixe de incendios descontrolados, polo que, nas advertencias ou normas penais que regulamentaban o control do lume, foron considerados tamén a carón doutras actividades.

Máis importantes e frecuentes foron as advertencias cara a outras actividades, como eran o pastoreo e a decrúa de novos espazos para o cultivo, que, de resultas do importante crecemento demográfico que se acadou neste período (desde comezos do XVI ata finais do XVIII duplicouse a poboación de Galicia e Portugal), 


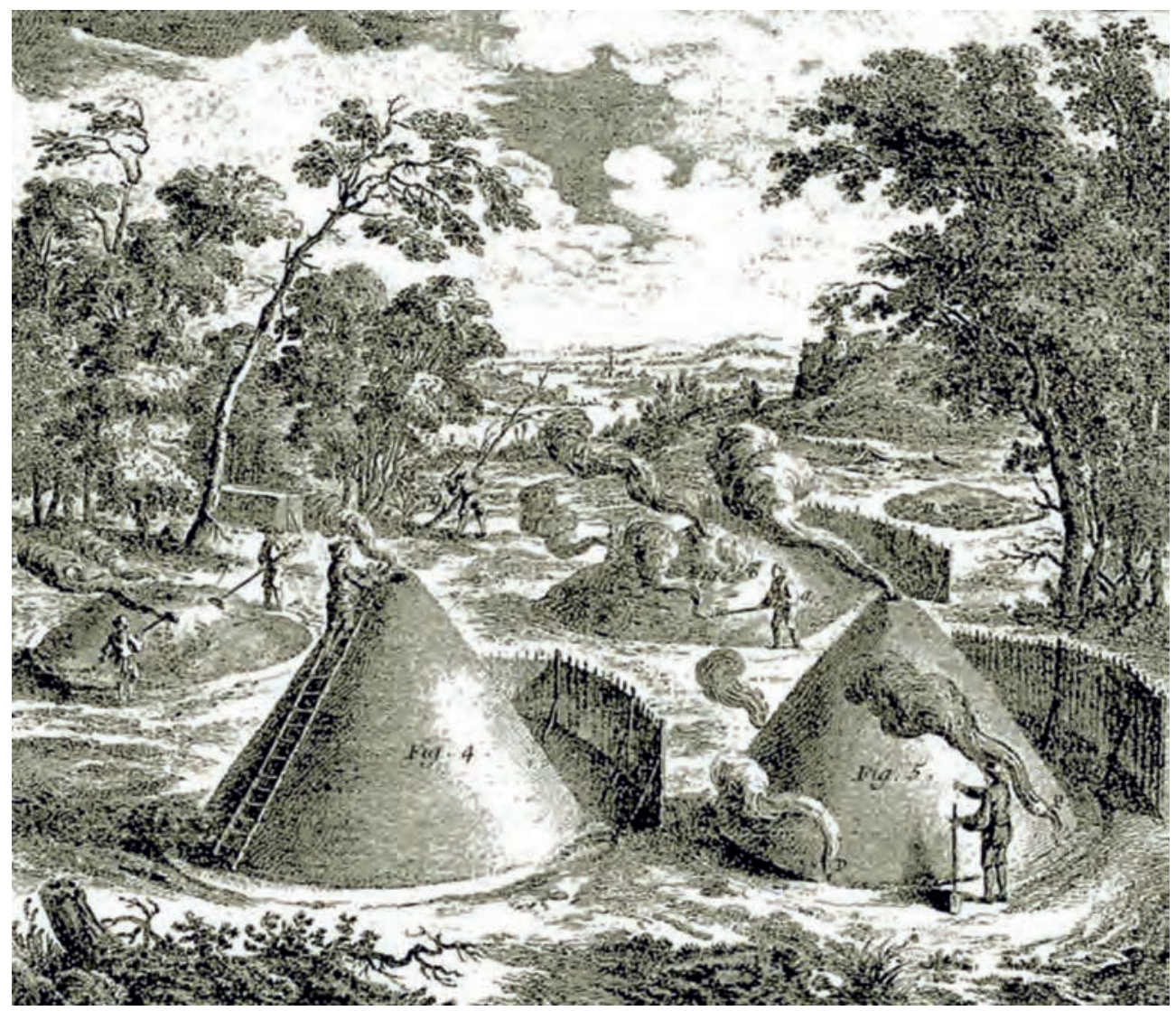

Figura 5. Carboeiros fabricando carbón vexetal (da Enciclopedia francesa)

foron, sen dúbida, as principais actividades xeradoras de incendios, os cales, cando as condicións meteorolóxicas non eran as axeitadas, polas secas e o vento, se propagaban por todo o país, tal como recolle unha crónica de Santiago do ano 1685: «[T] an secos fueron el verano y el estío de 1685, que se agotaron las fuentes y río; ardían los montes» (Fontana 1977).

$\mathrm{O}$ pastoreo nas zonas de monte incrementouse dun xeito importante polas necesidades de carne, leite e la que unha poboación en medra constante esixía, aínda que ao longo deste período se constatou un decrecemento dos efectivos gandeiros no monte. En xeral, tratábase dunha actividade que competía coa agricultura e a silvicultura e que na maioría dos casos, sobre todo cos grandes 
rabaños, era depositaria duns dereitos protexidos polo clero, os nobres e os mesmos monarcas. A práctica das queimas para rexenerar os pastos constituía a norma que ninguén dubidaba en aplicar e incluso, coas primeiras lexislacións sobre lumes, houbo unha certa permisividade que, co tempo e coa reiteración dos incendios que se xeraban, foi desaparecendo. Neste período, case todas as serras galaico-portuguesas estaban deforestadas e mesmo, bioloxicamente, moi degradadas polo pastoreo intensivo a que eran sometidas.

De todas as maneiras, a actividade á que se lle poden atribuír a maioría dos incendios da época foi a das novas decrúas do monte mediante o lume. Todas as lexislacións e normas que se foron redactando fan referencia a elas e, por outra parte, existe unha gran coincidencia entre os historiadores en afirmar que os rendementos dos cultivos por superficie medraron moi pouco neste período, polo que as necesarias achegas en cereais que se precisaban como alimento dunha poboación que ía en aumento só podían vir dunha ampliación da superficie cultivada. Dado que nesta altura as terras de vocación agrícola (vales e costas achanzadas por aterrazamentos) estaban xa practicamente ocupadas polos cultivos, a única ampliación posible era a partir de decrúas do monte sobre solos cada vez menos produtivos. Deste xeito, o risco de incendios ía espallándose polo monte en ondadas de cultivo itinerante cada vez máis amplas.

De resultas de que o lume fose afectando cunha frecuencia crecente a zonas en costa, a erosión do solo demostrou ser tamén unha consecuencia case inevitable dos lumes, que deixaban as súas pegadas máis evidentes na obstrución dos canais fluviais. Destes efectos hai testemuños tan antigos como as prohibicións da cidade de Coimbra de 1464 de facer fogos a menos de media legua das marxes do río (carta rexia de Afonso V), reiteradas en 1492 polo "grande dano que o campo da [súa] çidade de cojimbra Reçebe pelas mujtas áreas que nelle rrecreçem por causa dos mujtos fogos que se pooeem per as matas e charnecas arredor do Rio mondeguo». Máis adiante e xa en Galicia e Asturias no século XVII, as rías do Cantábrico experimentan un proceso acusado de perda de caudal que o marqués de Sargadelos atribúe en 1778 aos numerosos incendios que acontecen nos montes:

¿A qué parte arrojaremos la vista en que el fuego repetido de 6 en 6 años por una reprensible é inveterada costumbre no haya llevado á un punto final la desolación? $[\ldots]=[\ldots]$ 
Los bosques mas soverbios de roble, muy comunes antes de ahora en Asturias y Galicia, han desaparecido en la mayor parte, y en su lugar solo se miran montañas decepadas, valles talados, colinas debastadas [...]. = A estos perjuicios se siguen otros secundarios é inevitables. Las aguas que se forman de las lluvias, exemptas del embarazo de las espesuras y malezas [...], se despeñan y precipitan desde lo mas alto de las cumbres hasta lo mas profundo de los valles y de los rios, llevando lo mas precioso de la superficie hasta llegar al barro ó peña, y dexando el suelo reducido á erial [...]. = De aqui tiene origen el haberse visto en nuestros dias (ó quando mas desde el principio de este siglo) atollar muchos de los Puertos de mar casi inhabilitados para la navegacion mercantil.

(Casariego 1950)

A importancia que tanto en España como en Portugal foi adquirindo, a partir do século XVI, a construción de barcos para atender as necesidades cada vez máis urxentes dos seus amplos imperios coloniais causou que a madeira dos bosques se fose convertendo nun recurso estratéxico de interese nacional. Moitas masas forestais foron declaradas de «interese real» e pasaron a ser xestionadas pola Mariña, que ditou normas e dispuxo medios para a súa protección. Una nova silvicultura deu en nacer de mans destes técnicos, que non só tentaron protexer aqueles recursos, senón que, sobre todo, empezaron dun xeito sistemático a repoñer as masas forestais con repoboacións en novos plantíos.

Nos dous países, toda unha nova lexislación forestal comezou a xurdir con profusión e nela, con maior ou menor insistencia, a preocupación polo control dos lumes foi sempre un tema recorrente. De grande interese son as denominadas Ordenacións manuelinas (de Manuel I), nas que xa en 1521 se fai mención da necesidade de controlar o sotobosque como medida de prevención do lume: «[...] pelo facto dos pinhais não serem limpos do mato, seguem-se grandes inconvenientes de serem queimados» (Monteiro et al. 2006). Máis adiante o rei Filipe II (Filipe I de Portugal), que tiña un interese moi particular pola defensa das árbores e xardíns (Bauer 1980), volve insistir, nas denominadas Ordenacións filipinas (1603), nos perigos dos incendios forestais e na necesidade de que os veciños acudan por obriga ao seu control:

Defendemos, que nenhuma pessoa, de qualquer qualidade e condição que seja, ponha fogo em parte alguma, e pondo-se algum fogo em lugar, que possa seguir dano, os Juizes 
e Officiaes das Cidades, Villas e lugares, onde se taes fogos alevantarem, acudão e fação a elles acudir con muita diligencia, para prestes se haverem de apagar [...].

Descríbese despois toda unha sorte de medidas punitivas que ían desde a compensación de danos ata a deportación por dous anos en África (Monteiro et al. 2006).

Pódese sinalar igualmente que foi neste período cando comezou a expansión en Portugal do piñeiro bravo (Pinus pinaster), especie cunha especial proclividade ao lume e responsable, nalgunha medida, dos incendios forestais posteriores. Fronte á prioridade que lle outorgaba a lexislación española -por exemplo, en Galicia-á repoboación, nos plantíos da Mariña, coas especies eurosiberianas dos Quercus, no caso portugués foi o piñeiro bravo a especie de preferencia. O Pinhal do Rei de Leiria, de máis de 10000 hectáreas, iniciado no século XIII, nos tempos de Alfonso III, con plantacións de diferentes especies de piñeiro, a finais do século XV estaba fortemente degradado polos moitos incendios que o afectaron e as cortas fraudulentas a que fora sometido. Filipe II rexenerouno por completo, pero, neste caso, con plantacións exclusivas de piñeiro bravo, das que saíu unha boa parte das madeiras coas que foi construída a frota de navíos portuguesa. A partir do emblemático piñeiral semella que houbo unha importante difusión desta especie forestal; de todas as maneiras, non se pode desbotar que en moitas zonas do interior xurdisen plantacións resultantes da rexeneración de pequenos enclaves da dita especie, propia da historia forestal portuguesa. En Galicia, de acordo con Ruiz Zorrilla (1980), a penetración do piñeiro bravo puido comezar a finais do século XVII no Baixo Miño, procedente de Portugal.

Esta época remata tanto en Galicia como en Portugal co alento reformador da Ilustración, que achega formulacións racionalistas e sistemáticas sobre a problemática forestal. Aínda non existía a silvicultura en canto ciencia propia e ben definida, o que sería tarefa do século seguinte, pero xa os métodos de abordaxe da temática forestal se empezaron a facer cos novos coñecementos en economía e en ciencias naturais que a razón e o método fornecían. Para o territorio galego-portugués houbo dúas personalidades ilustradas que souberon encarar a problemática dos bosques, e nomeadamente o tema dos incendios, con este pensamento renovador: o político e mineraloxista brasileiro, profesor en Coimbra, José Bonifácio de Andrada e Silva, quen en 1803 foi nomeado Guarda-Mor de 
Bosques e Matas e que en 1815 publica o primeiro libro portugués sobre silvicultura, Memoria sobre a necessidade e utilidade do plantio de novos bosques em Portugal. Deseñou as novas repoboacións dos areais costeiros e, sobre todo, tiña unha formulación moi na liña humboldtiana da utilidade dos bosques na mellora das calidades do aire e das augas. Destacou con claridade os efectos negativos das deforestacións das encostas polo incremento da erosión e das cheas, sinalando «as queimas dos pastores» como unha das causas relevantes destes problemas.

O ilustrado Antonio Raimundo Ibáñez, marqués de Sargadelos, tiña unha preocupación permanente en relación coa necesidade de manter en condicións dunha axeitada explotación económica os bosques da mariña luguesa e asturiana. E, aínda que o carbón vexetal que precisaban as súas factorías era unha das causas importantes da deforestación, propoñía que o consumo de madeira que necesitaban fose compensado con novas plantacións, como a que realizou no contorno de Sargadelos, nun réxime de aproveitamento sostible. Escribiu sobre os danos dos incendios, aos que lles atribuía, segundo xa se comentou,

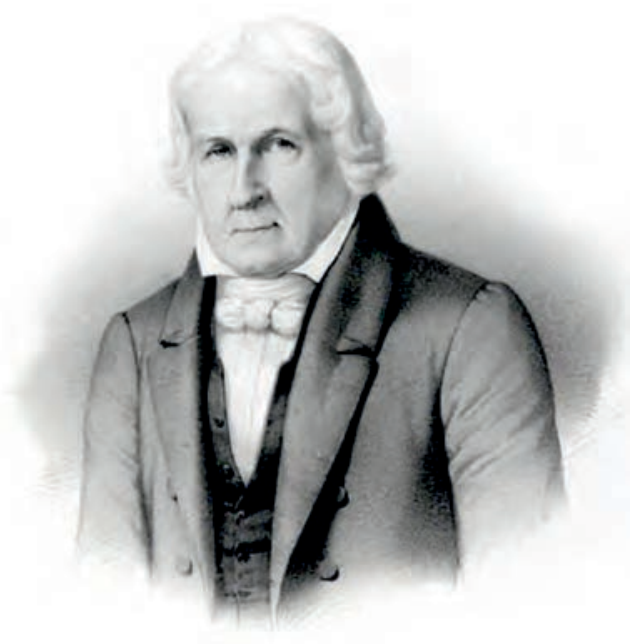

Figura 6. José Bonifácio de Andrada e Silva (1763-1838)

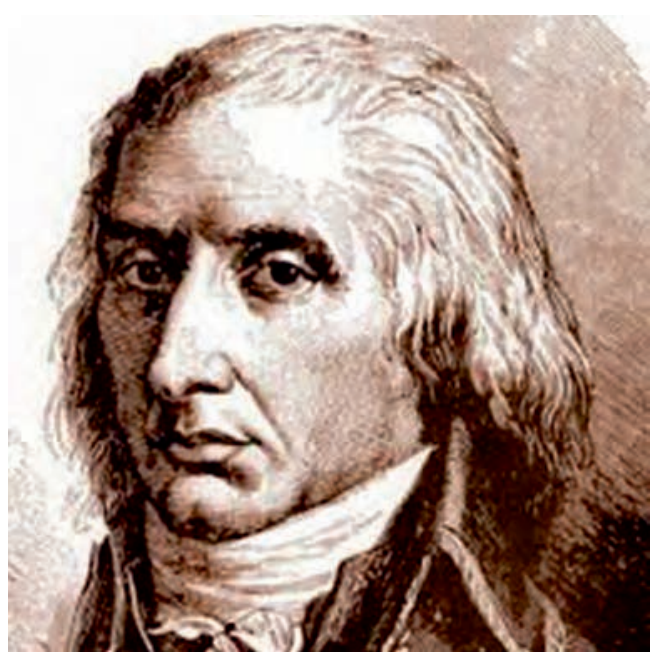

Figura 7. Antonio Raimundo Ibáñez, marqués de Sargadelos (1749-1809) 
graves problemas de erosión e arrastres cara ás rías, pero, sobre todo, clamou contra eles nos seus Discursos económico-politicos sobre la restauración de los montes y plantios en España (1802):

A pesar de la multitud de enemigos que por todas partes asaltan a nuestros montes, nunca hubieran llegado al estado deplorable y lastimoso a que se hallan reducidos si la legislación desde un principio se hubiera esforzado a desterrar los incendios. No es posible dar una idea cabal de los males que han causado.

[...] las aguas de las riadas que suceden a las quemas, libres de los estorbos de las malezas que antes detenían, se precipitan con violencia, arrastran y llevan consigo las cenizas y todo lo que es movible hasta llegar al barro y a la peña.

[...] El fuego abrasa y devora en un día el bien gratuito que a la naturaleza le costó muchos siglos. Se puede decir que entre todos los desórdenes es el enemigo más temible y destructor de los montes.

[...] A cualquier parte que miremos no se ven sino colinas abrasadas, montañas desnudas, cañadas y quebraduras devastadas, comunes y baldíos pelados, y tal o cual reliquia de algunos bosques feraces que pugnan todavía por conservarse.

\section{O BOSQUE E OS INCENDIOS NA ERA DAS TÉCNICAS}

Seguindo co esquema de Bowman et al. (2011), agora entrariamos nas etapas E e F, correspondentes á Revolución Industrial e a modernidade. Esta nova etapa podería coincidir, desde o punto de vista dos incendios forestais, co cambio de «fase» antropoxénica que propoñían Pausas e Keeley (2009) sobre unha idea anterior de Guyette et al. (2012). De acordo con estes autores, arredor de $1850^{2}$ prodúcese un cambio dos incendios que cualifican de «dependentes da ignición» cara aos «limitados polo combustible» (Guyette et al. 2012) ou "controlados polo combustible» (Pausas e Keeley 2009). No primeiro caso serían fundamentalmente as actividades antropoxénicas e, como referentes delas, a densidade da poboación rural ou a superficie agraria as determinantes dos incendios, mentres

\footnotetext{
2 Esta data refírese á experiencia americana, na que se basearon Guyette et al. (2012), pero apuntan que pode variar duns países a outros.
} 
que no segundo caso, acadado xa o teito da expansión da poboación, sería o amoreamento e manexo do combustible a súa causa fundamental.

De todas as maneiras, estimamos máis acaído utilizar, para definir esta nova época dominada pola industrialización e a técnica, a división establecida por Monteiro et al. (2006) sobre a importancia que ten nesa etapa a chegada dos novos técnicos forestais saídos do ensino superior, grazas aos que, "pela primeira vez, vamos encontrar, entre nós, expressões de verdadeiro carácter técnico a respeito de ideias ou conceitos sobre combate ou defesa contra incêndios florestais, não a simples constatação dos riscos e das punições [...]». Antes poderiamos estar a falar de afeccionados máis ou menos acertados; agora xa estariamos diante de verdadeiros técnicos silvicultores.

En Portugal, antes da creación dos primeiros cursos superiores de ensino silvícola, habería que destacar o alemán Friderico L. G. de Varnhagen, que foi nomeado Administrador Geral das Matas e é autor dun fundamental Manual de Instruçôes práticas sobre a sementeira, cultura e cortes dos Pinheiros (1836), no que aparece, citado con gran precocidade, o interese que ten para o bosque a realización de fogos controlados fóra da época de incendios como «un meio seguro de libra-lo de ser incendiado no verão». Tamén se lle debe a que foi posiblemente a primeira rede de devasas de prevención de incendios construída na Península, que foi comezada en 1826 a partir dunha densa malla ortogonal delas de 10 e 20 metros de ancho.

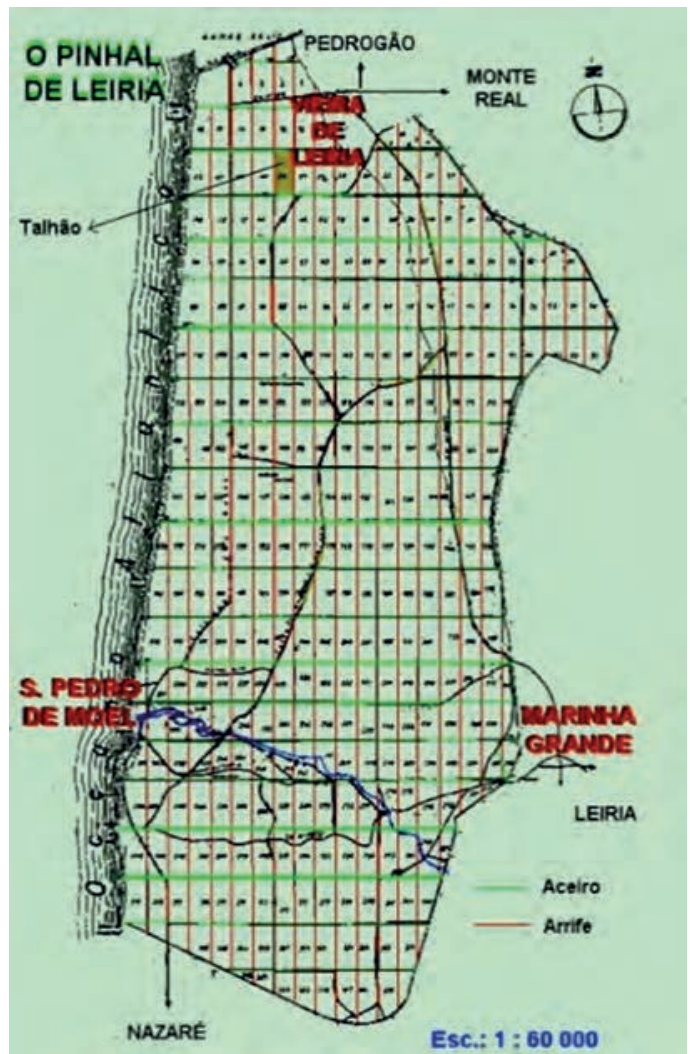

Figura 8. Rede de devasas do Pinhal de Leiria 


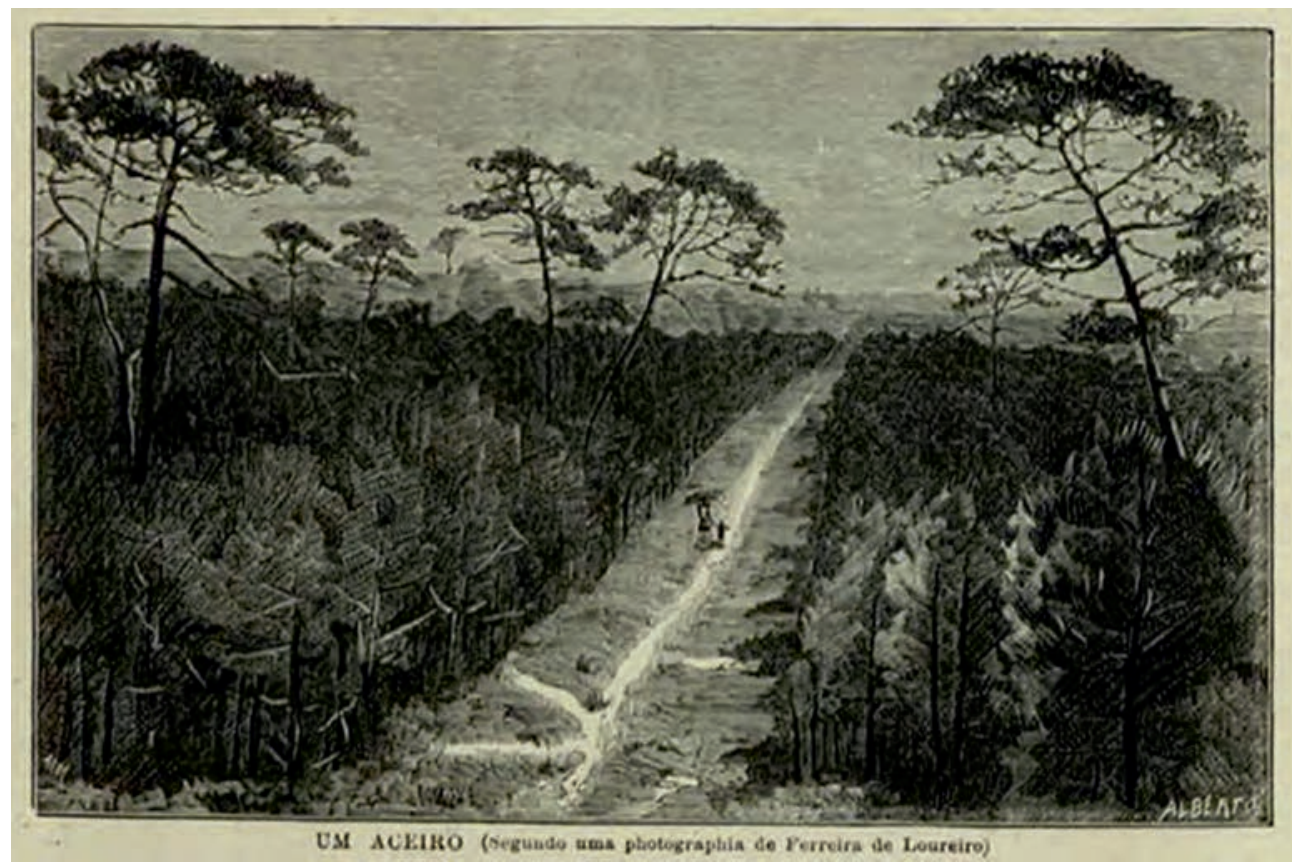

Figura 9. Devasa (aceiro) no Pinhal do Rei en Leiria (1909)

Os primeiros forestais portugueses con estudos superiores saíron en 1864 do Curso Superior de Silvicultura do Instituto Geral de Agricultura do Porto. Antes, algúns técnicos forestais portugueses tiveran unha boa formación silvícola en Alemaña, nomeadamente na Academia de Tharandt, fundada e dirixida polo pai da dasonomía, Heinrich Cotta.

En España, inspirada nestes mesmos principios científicos da silvicultura alemá, foi creada en 1846 a Escola Superior de Enxeñeiros de Montes, de onde saíron os primeiros técnicos forestais, que fixeron a súa chegada a Galicia en 1859. Antes, como acontecera en Portugal, falaron do monte e dos seus problemas «afeccionados» tales que o médico Gil Rey e o naturalista Valenzuela (Díaz-Fierros 2006). Como consecuencia de que a formación técnica dos primeiros forestais españois e portugueses bebese nas mesmas fontes, poderíase dicir que estaba inspirada polo que se denominou o «naturalismo forestal», imbuído do pensamento humboldtiano, que tiña como idea central a do equilibro e harmonía da natureza (Casals 1988). 
O comezo desta época coincide tamén, posiblemente, coa superficie mínima acadada polo espazo forestal (entre o $10 \%$ e o $15 \%$ da superficie total) e os inicios da repunta do proceso reforestador mediante repoboacións que caracterizou todo o século XIX e boa parte do XX. Este mínimo conseguiríase antes en Portugal (quizais a mediados do XVIII) e, polo tanto, o proceso repoboador foi, de igual modo, máis precoz que en Galicia. En calquera caso, o que resulta evidente é que todos os incesantes desvelos da Administración da Mariña, desde o século XVI, para establecer plantíos que fornecesen de madeiras os seus estaleiros remataron nun sonoro fracaso. Así mesmo, toda a reconquista do espazo forestal que se deu a partir deste momento tivo como protagonista principal o piñeiro bravo, que, desde o seu recanto tradicional de Leiria, podería dicirse que chegou a dominar, nun proceso que durou ata a metade do século XX, a maior parte do territorio forestal galego-portugués. Os datos correspondentes ás superficies dedicadas ao piñeiro bravo en Galicia e Portugal son os recollidos na táboa I.

Táboa I. Evolución das superficies (en hectáreas) dedicadas ao Pinus pinaster en Portugal e Galicia

\begin{tabular}{|l|l|l|}
\hline & Portugal & Galicia \\
\hline 1752 & 15000 & 240 \\
\hline 1859 & & 6689 \\
\hline 1875 & 210000 & \\
\hline $1902-1903$ & $430000-913000$ & \\
\hline 1928 & 1131500 & \\
\hline 1947 & & 300000 \\
\hline 1959 & & 500000 \\
\hline 1966 & 1287000 & \\
\hline $1972-1973$ & & 616000 \\
\hline
\end{tabular}

Datos de Ruiz Zorrilla (1980), Devy-Vareta (1999), Beiras (1967) e Molina (1979). Os datos galegos dos inventarios de 1947 e 1959 son os calculados a partir dos valores correspondentes ás categorías «P. pinaster» $\mathrm{e}$ «mesturas»

No territorio galego-portugués pódese demostrar que tamén, máis ou menos na primeira metade do século XIX, se chega case aos máximos da expansión 
territorial do mundo rural e que a partir de agora a medra da poboación, aínda que vai seguir progresando ata as primeiras décadas do XX, se vai sustentar sobre todo no crecemento de vilas e cidades. Estas, pola súa vez, absorberán os excedentes da poboación rural que non teñan recursos para subsistiren, nun proceso xa imparable de emigración campo-cidade que se complementará, no último terzo do XIX, cun forte incremento da emigración cara a América.

Esta poboación asentada no rural, a pesar do forte aumento das rozas que se provocou no devandito período, desenvolverá, ao mesmo tempo, un eficaz proceso de control do combustible, centrado maiormente no mato de Ulex, a partir de actividades tales que a recolección do estrume para fertilizante das terras (Bouhier calcula que se utilizaba como mínimo unha superficie de mato dobre da que tiñan as terras de labradío, polo que, segundo a súa xa clásica sentenza, «o monte era o soporte dos cultivos»), fonte de calor, alimentación do gando, protección de camiños etc.

Pese ao antedito control do combustible, esta época vai coñecer un incremento dos incendios utilizados en forma de protesta do campesiñado fronte aos drásticos cambios que se van producir tanto en España como en Portugal en relación coa titularidade e uso do monte, sobre todo a partir dos procesos de desamortización e os intentos de estatalización dos sistemas comunais e tradicionais de aproveitamento deste espazo. A irrupción dos réximes autoritarios do Estado Novo e do franquismo, cos seus métodos expeditivos de apropiación do uso do monte, radicalizou as posturas e as respostas do campesiñado.

Eses incendios de carácter sociopolítico víronse acompañados dos xa clásicos fogos descontrolados xerados polo pastoreo e a agricultura de rozas, así como polas queimas de restroballos. E tamén apareceu algunha forma nova de incendios: por exemplo, a dos lumes derivados das actividades excursionistas, en medra crecente sobre todo no contorno das cidades (Díaz-Fierros 2006). De igual modo, pódese sinalar como característico deste período que a prensa comece xa a facerse eco dos casos máis salientables e que apareza unha literatura máis ou menos impregnada do pensamento rexeneracionista, maiormente de Costa (entre os exemplos españois poderíanse citar La locura de los pastores [1910], de Federico Rahola; La canción del Duero [1919], de Julio Senador; Murmullos de la selva [1923], de Ignacio Elorrieta, e El riesgo de los incendios en los montes [1927], de Antonio Lleó). 
En Portugal foi moi sinalada a reportaxe da Ilustração Portuguesa (suplemento de $O$ Século do 4 de setembro de 1916) sobre un grande incendio do Pinhal de Leiria, na que se amosaba, no contexto da literatura dramática que suxería, unha visión realista do incendio:

As chamas rebentaram em três pontos ao mesmo tempo. Tocadas pelo vento e alimentadas pelo mato miúdo e pela caruma seca que cobriam o solo, não tardaram a cruzar-se num grande mar de fogo. Una coisa sublimemente horrível!

Buzinas, apitos, toques de sino, gritaria, alvoroçaram as povoaçōes convizinhas, das quais a principal é a vila da Marinha Grande. Nas fábricas, nos campos, em casa não ficou ninguém. Todos munidos de enxadas, machados, pás, forquilhas, ancinhos, do primeiro instrumento que topavam à mão, abalaram desordenadamente para atacar o fogo [...].

E, sobre todo, unha descrición detallada do combate contra o fogo que paga a pena coñecer cun certo vagar:

$\mathrm{Na}$ fúria com que toda a gente se atirava ao fogo não havia visivelmente um plano de ataque, executando a uma voz imperiosa de comando; mas havia uma perícia e uma tática individuais que davam ao conjunto dos esforços uma admirável unidade de ação. Abrem-se aceiros, compridos e largos, machadando sem piedade belas árvores para atalhar a marcha galopante do fogo, que as devoraria, a elas e a muitas mais, sendo admirável como essa gente se estendia numa linha rigorosa de combate, sen se estorvar uma à outra.

$[\ldots]$

[...] [C]ontinuavam a manejar o machado [...]. Outros roçavam o mato e procuravam arredá-lo do caminho do fogo; estes deitaban pás de terra sobre a vegetação miúda para o abafar; aqueles abriam arrifes à enxada tentando atalhar-lhe a marcha de todas as formas possíveis.

Pero quizais o máis sobresaínte sería o xeito en que se estaba a utilizar xa unha técnica tan innovadora naquela altura como a do contrafogo:

[...] [A] fase culminante da batalha é o contrafogo. Abre-se um aceiro largo. Lança-se lumo, bem entendido [...]. 
[...]

Segue-se então brusco um silêncio de morte. Se o mar encrespado, bramindo furioso, se estagnasse de súbito num lago dormente, não nos chocaria mais brutal impressão de contraste. Até o vento se acalmou. A forte exclamação de vitória...

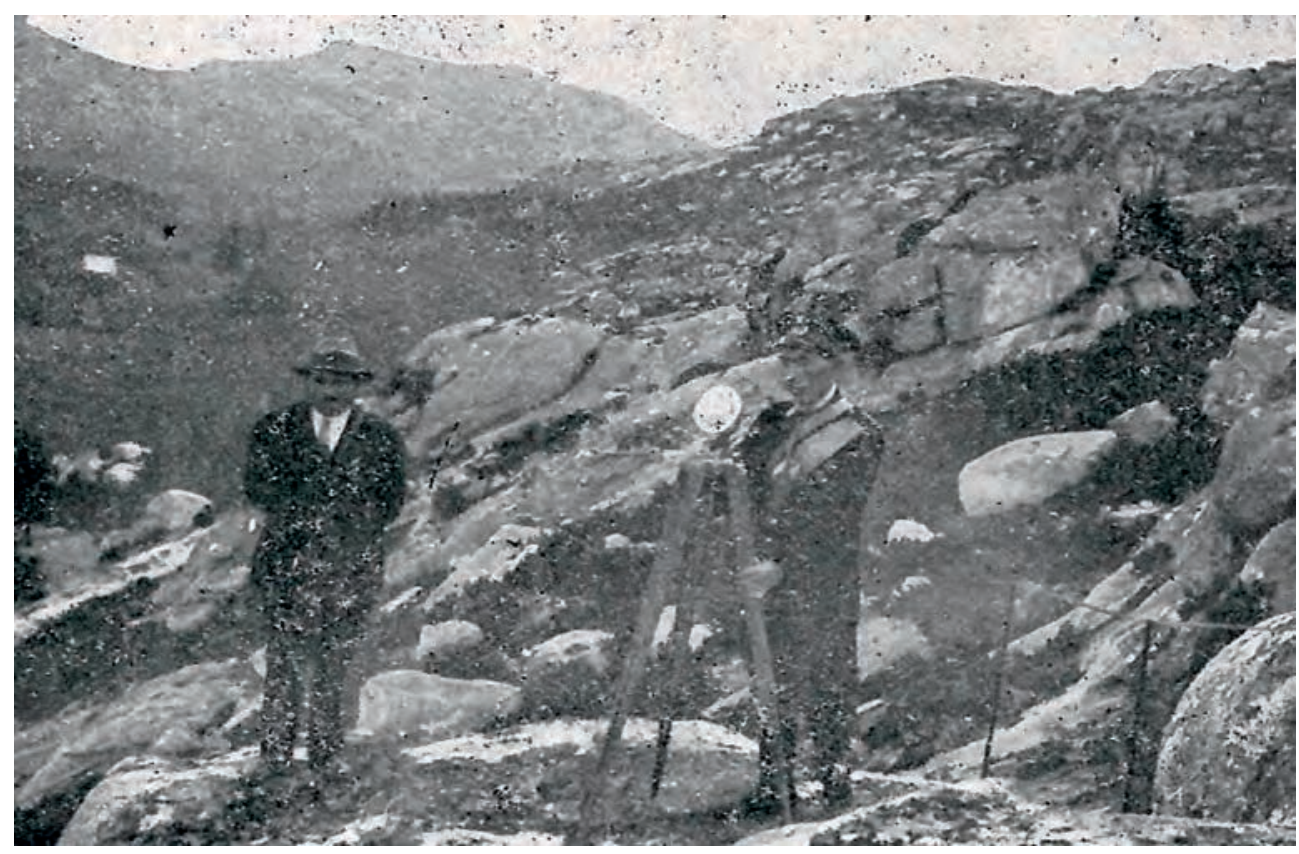

Figura 10. Garda forestal transmitindo información mediante un heliógrafo sobre un incendio en Oia (Galicia) (Areses 1929)

Estas descricións do incendio de Leiria, onde aparecen os contrafogos, sumadas ás técnicas de creación de devasas coñecidas e practicadas desde bastantes anos antes, sitúannos xa diante das novas técnicas que se estaban a desenvolver na loita contra os incendios forestais. Ao tempo, outras novidades técnicas, como a transmisión de sinais a distancia co heliógrafo e, posteriormente, coa telefonía, contribúen a que os avisos e a coordinación poidan realizarse en períodos máis curtos.

Por outra parte, todos os plans de repoboación que se poñen en marcha levan incorporadas medidas moi explícitas sobre o control na prevención e extinción 
dos incendios, e está xeneralizada a práctica, neste último caso, da obrigatoriedade de os veciños acudiren sempre que os servizos forestais e a forza pública o demandasen, segundo describe Areses (1929) no seu libro:

Al notar la presencia del fuego, deberán los pedáneos avisar a los vecinos, dando señales de alarma por medio de bocinas, campanas, etc. Provistas las gentes de azadas y ramaje de los árboles que se encuentren al paso, se pondrán a las órdenes del Guarda Forestal, de la Guardia Civil o en su ausencia, de personas capacitadas para asumir la dirección de los trabajos de extinción. Se distribuirá la gente rápidamente a lo largo de la línea de fuego, procurando que quede a sus espaldas un camino, no solo para asegurar la retirada, sino por la mayor facilidad para moverse y detener el fuego. Mientras unos azotan las llamas con el ramaje, los otros manejarán la azada para arrojar tierra y abrir cortafuegos o zanjas cuando el fuego sea subterráneo.

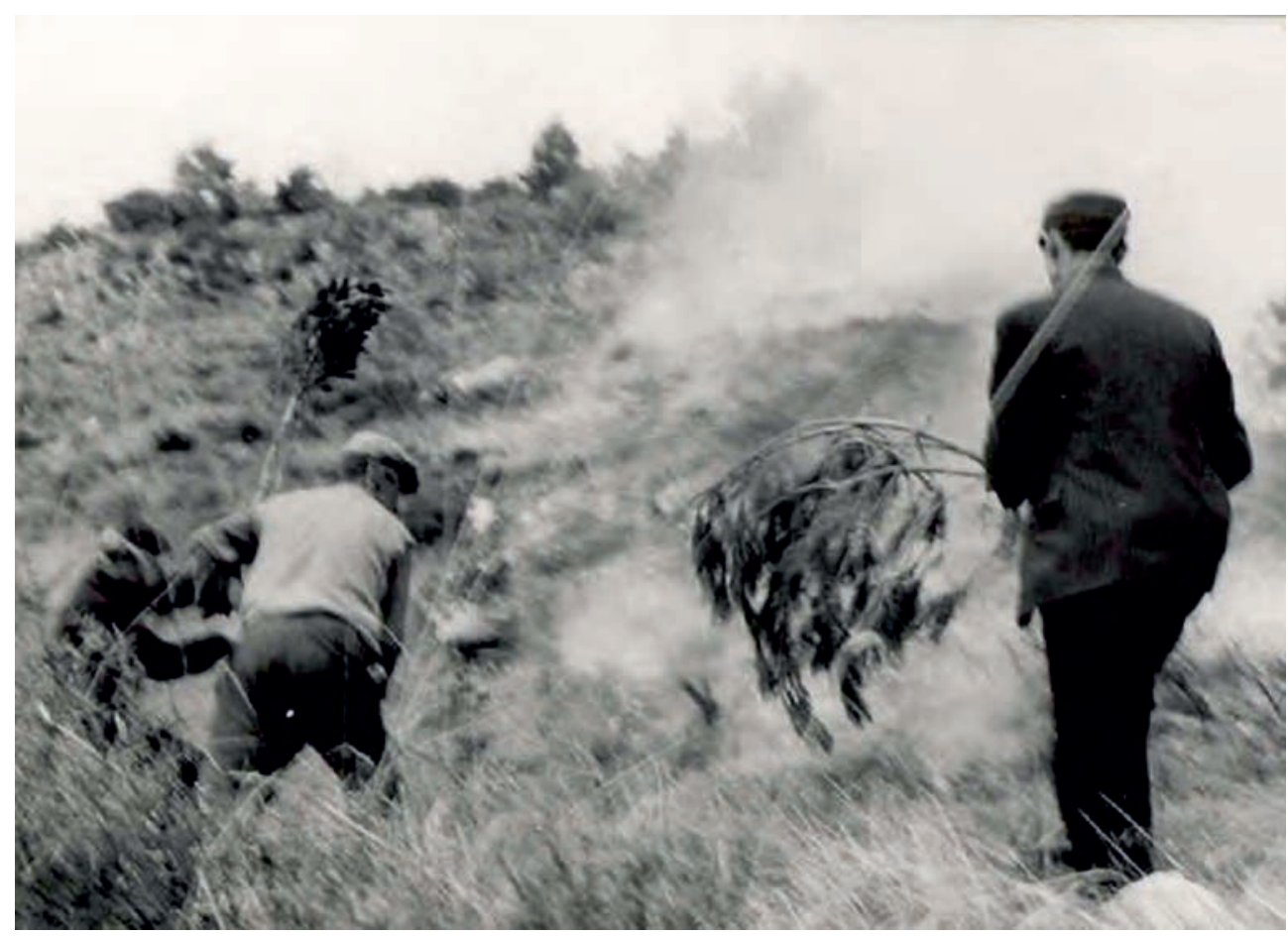

Figura 11. Extinción de incendios forestais con métodos tradicionais (Vélez 2015) 
Foi unha época en que, aínda que as novas repoboacións forestais ocupaban xa amplos espazos do territorio galego-portugués en masas, en moitos casos compactas de máis, os incendios, grazas ao control do mato polos agricultores, poucas veces superaban individualmente o centenar de hectáreas e o cómputo anual en raras ocasións excedía as 5000 .

\section{O DESARTELLAMENTO DO MUNDO RURAL. DOS SESENTA EN DIANTE}

Os procesos de desenvolvemento económico que se inician nos dous países a partir dos anos sesenta, xunto co atractivo da florecente Europa como destino das poboacións empobrecidas das áreas de montaña, entre outras razóns, xeraron un fluxo imparable de abandono do campo dos recursos humanos máis activos. En Galicia, entre 1960 e finais dos oitenta os ocupados agrarios pasaron de 660000 a 330000 e nos principios do século XXI xa se estaba nos 110000 . En Portugal, a poboación activa agraria pasou de millón e medio de traballadores en 1950 a un terzo menos en 1970 e algo menos da metade en 1981.

Este éxodo masivo motivou que as prácticas tradicionais de control do mato que estaban a actuar desde tempos inmemoriais no monte deixasen de levarse a cabo e comezase o amoreamento de combustible nesas zonas. E resulta sintomático que, ao remate de menos de dez anos, cando a acumulación de biomasa acadou niveis importantes e as condicións meteorolóxicas non foron as axeitadas, se iniciase a progresión dos incendios, que superaron a barreira das 20000 ha anuais queimadas no ano 1968 en Portugal e no 1972 en Galicia. Despois empezou unha tendencia crecente na que se excederon as 100000 ha en Portugal no ano 1975 e en Galicia no 1978. Ao tempo, o número de sinistros en Galicia xa superara os 6000, mentres que en Portugal estaban aínda por baixo dos 500. De todas as maneiras, este reducido número de ocorrencias agachaba a contrapartida dalgúns megaincendios que aconteceran naquela altura, como o de Vale do Rei (1961), de 2500 ha; Viana (1962), 5000; Sintra (1966), 5000; Vila de Rei (1980), 12000, e Arganil (1981), con 10900 ha (Ferreira-Leite et al. 2013). Esta particularidade portuguesa estaba a indicar, posiblemente, que as masas combustibles -árbores e mato- tiñan unha maior continuidade que no 

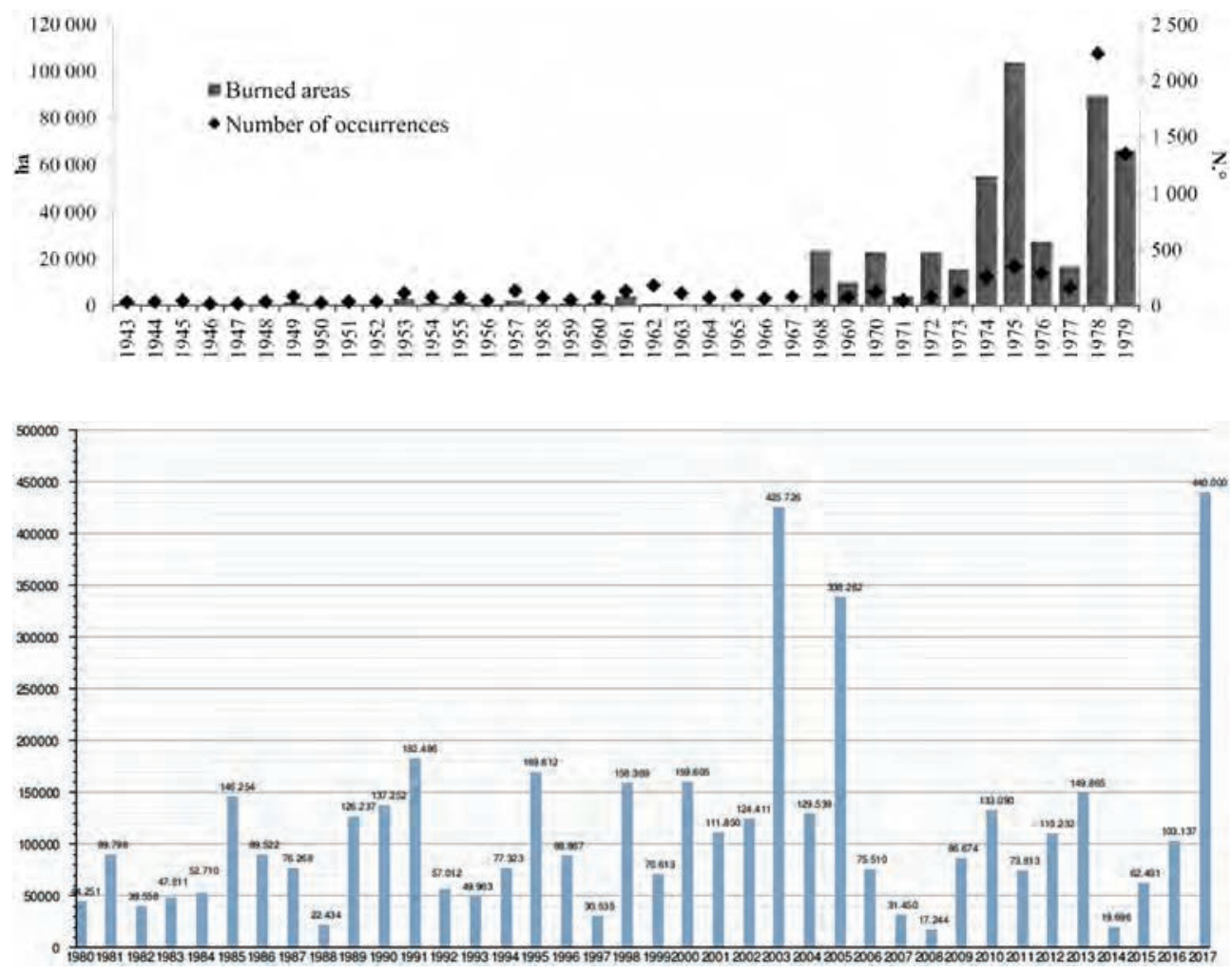

Figura 12. Incendios forestais en Portugal (1943-2017)

caso galego, onde a fragmentación da propiedade daba orixe a unha paisaxe moito máis promiscua e minifundista e, como consecuencia, a incendios individuais menores.

Os anos oitenta caracterízanse por un recruar da onda incendiaria, na que Galicia supera de novo, por tres veces, a barreira das 100000 ha anuais (en 1981, 1985 e, sobre todo, en 1989, co máximo ata agora acadado das 205000 ha). En Portugal, igualmente se supera en tres ocasións a barreira das 100000 e, como dato principal, o número de incendios sitúase xa por enriba dos 5000. A década dos noventa, co importante incremento que experimentan os medios de extinción en Galicia (chegan a multiplicarse por cinco os orzamentos), trae como consecuencia que a superficie queimada se reduza drasticamente, con valores, en 


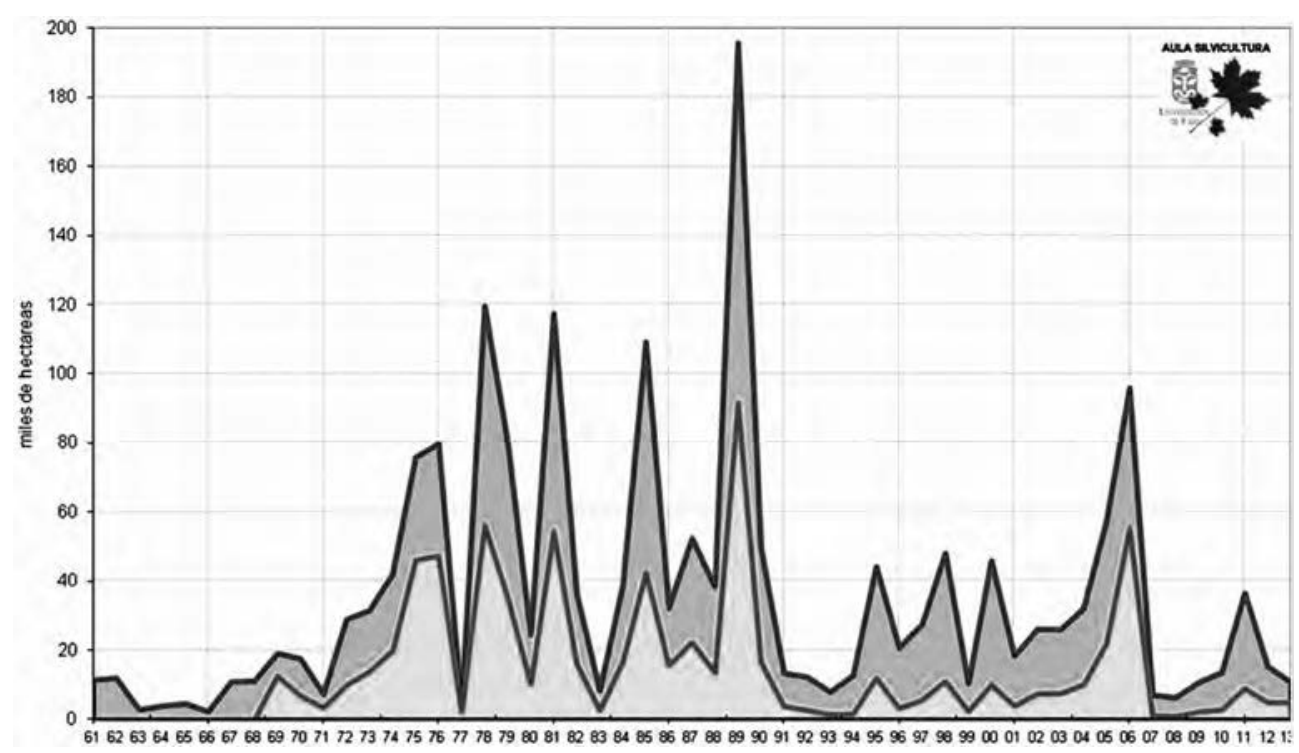

Figura 13. Evolución da superficie queimada en Galicia (1961-2013)

xeral, por baixo das 20000 ha anuais, agás algúns anos en que, polas adversas condicións meteorolóxicas (1995, 1998 e 2000) se achega ás 50000 ha. En Portugal, en cambio, non hai inversión na tendencia, con catro anos por enriba das 100000 ha e manténdose moi elevado, así mesmo, o número de sinistros (entre 15000 e 30000$)$.

Co novo século a tendencia de fondo mantense, en Galicia sobre as 20000 ou 30000 ha e en Portugal sobre as 50000 ou 100000 , con anos excepcionais como o 2006, para Galicia, con 60000 ha, e para Portugal o 2003, con máis de 426000 , e o 2005, con 340000 ha. Finalmente, o ano 2017 foi tráxico para os dous países, con 440000 ha queimadas en Portugal e máis de 50000 en Galicia e cun balance de varias decenas de mortos.

Como consecuencia dese espectacular incremento dos incendios e acorde coa importancia que os factores técnicos foron acadando nestes tempos, os medios de extinción tamén foron evolucionando con rapidez. Dos métodos rudimentarios e predominantemente manuais que existían antes dos sesenta, pasouse en poucas décadas a dispor dun impresionante arsenal de dispositivos técnicos e de coordinación, xunto cuns orzamentos de decenas de millóns de euros. 
En España, os primeiros cambios viñeron da man das axudas estadounidenses como contrapartida da instalación das bases militares, que permitiron a compra de varios camións motobombas (en 1968 dispoñíase xa de 216 unidades) e, sobre todo, da primeira aeronave contraincendios, un Canadiar CL-215 que se probou en Galicia no ano 1969. En 1980 comeza a utilización dos helicópteros para desprazamento das brigadas aerotransportables, así como os primeiros ensaios de aplicacións do lume prescrito. $\mathrm{Na}$ década seguinte aparecen os sensores remotos para detección de incendios e, principalmente, a revolución informática en referencia ao tratamento e procesamento de datos. A coordinación entre os recursos das comunidades autónomas e do Estado, que ao inicio xerou bastantes problemas, axiña foi encamiñada coa integración dos diferentes servizos en unidades de mando único. A creación no 2005 da Unidade Militar de Emerxencias (UME) dentro das forzas armadas supuxo a dispoñibilidade de elementos humanos dotados de axeitada preparación técnica e facilidades para o seu desprazamento e integración nos operativos de extinción. Por último, o problema da erosión dos solos como consecuencia dos incendios, que foi formulado cientificamente a finais dos oitenta, a partir do ano 2015 deu orixe a medidas innovadoras de control postincendio. Galicia, en todas estas accións, con amplos recursos e medios e un persoal ben curtido na loita e prevención contra os incendios, constitúe na actualidade unha referencia dentro do Estado e mesmo da área mediterránea.

En Portugal, na década dos sesenta e no marco da loita contra o fogo, que dependía fundamentalmente dos servicios forestais, establecéronse uns Princípios Básicos de Luta contra Incêndios (redactados por Quintanilha, Silva e Moreira da Silva), que sentaban as normas dun operativo moderno e actualizado de extinción e prevención, pero a escaseza de medios e, sobre todo, o marasmo administrativo que se produciu pouco despois, coa dilución dos servizos de loita contra o fogo entre diferentes corpos administrativos (bombeiros voluntarios, Protección Civil etc.), restaron eficacia ás diferentes medidas que se foron adoptando. $\mathrm{Na}$ actualidade, despois do revulsivo social e político que supuxo a traxedia dos incendios de xuño e outubro de 2017, creouse unha comisión independente de análise e reflexión sobre o sucedido e, principalmente, con relación ás medidas que desenvolver no futuro, que deu orixe a un importante relatorio (outubro de 2017) que pode ser, se se atenden as súas recomendacións, un punto de inflexión na loita contra os incendios. 


\section{ESTAN QUEIMANDO GALICIA}

A lel de montes do 1.968 recofece que os montes son dos vecifios, e xa se estan a devolver en toda GALICIA. Pero os que sempre asoballaron ao pobe prendentles lume pra que non quede ninsunha riqueza pra os vecinos.

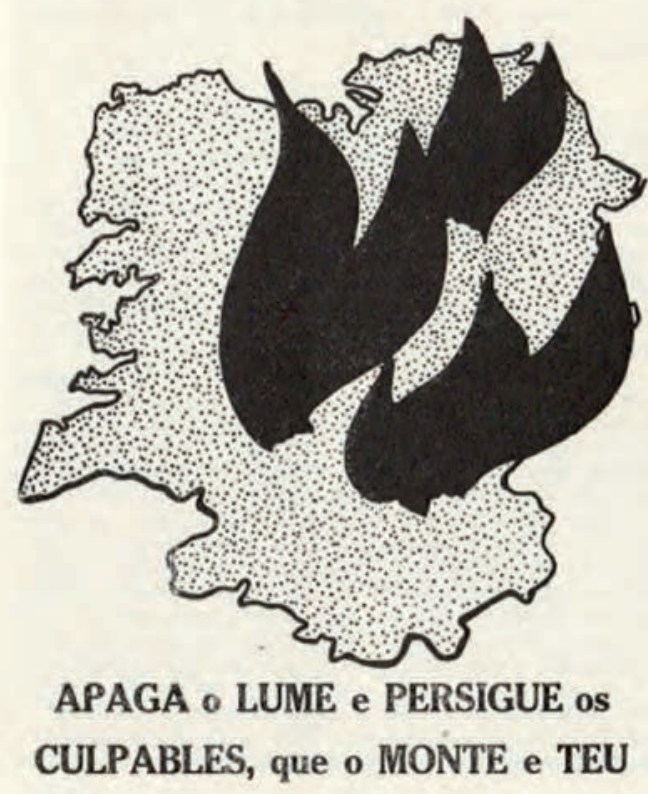

Corlinadora de Montes Conunales

Figura 14. Cartel de propaganda da campaña contra os incendios forestais da Coordinadora de Montes Comunais de Galicia (1977)
Finalmente, outra característica importante deste período constituíuna a repercusión social que foi adquirindo na opinión pública galaico-portuguesa o tema dos incendios forestais, que pasou de ser unha cuestión secundaria da que só se trataba de maneira circunstancial a figurar como asunto prioritario da axenda política e a ser noticia destacada dos medios de comunicación. En Galicia, posiblemente a primeira acción de toma de conciencia colectiva foi a promovida pola Coordinadora de Montes Comunais en 1977, con accións como o manifesto do Ateneo de Ourense polo Comité de Defensa dos Montes Galegos e as con-

ferencias de Pontevedra de 1978. Despois virían innumerables actuacións dos máis diversos colectivos cidadáns e de sociedades e organismos científicos. En 1987 o Parlamento galego, despois da importante vaga de incendios da década precedente, con tres anos en que houbo máis de 100000 ha ardidas, emitiu un ditame que contiña unha serie de recomendacións elaboradas por unha comisión técnica independente logo de varios meses de comparecencias dos colectivos máis implicados no tema. Tras os incendios do ano 2006, o Parlamento galego volveu 
pronunciarse oficialmente sobre esta cuestión. Pola súa banda, o Consello da Cultura Galega organizou dúas xornadas científicas: no 2006, Os incendios forestais en Galicia e, no 2007, Por unha nova cultura forestal fronte aos incendios.

As institucións científicas e técnicas de Galicia e Portugal desenvolveron desde os anos oitenta amplos e variados programas de investigación, postos en común en numerosas reunións científico-técnicas que deron orixe a continuadas e frutíferas colaboracións. $\mathrm{Na}$ actualidade pódese dicir que a comunidade da ciencia e da técnica dos dous países ten un pensamento compartido sobre a problemática dos incendios forestais que, por outra parte, constitúe unha recoñecida referencia no contexto europeo.

De todas as maneiras, moitos dos temas formulados nas discusións e reunións dos anos oitenta seguen aínda abertos, sobre todo na opinión pública, como son os relativos ás especies pirófilas (maiormente o caso do eucalipto) e o seu papel no risco de incendios, medidas preventivas de política forestal, control do mato, a caracterización, persecución e castigo dos incendiarios, medidas de extinción etc.

\section{UNHA NOVA XERACIÓN DE LUMES?}

Unha investigación realizada mediante satélite (Bowman et al. 2017) de 23000 incendios forestais detectados entre 2002 e 2013 por todo o mundo amosou que 478 podían ser clasificados como megaincendios pola súa extensión e elevada intensidade. Por outra parte, xurdiron estudos americanos (Heyck-Williams et al. 2017) e australianos que, á vez que constataban a presenza destes grandes incendios nos últimos tempos, detectaban tamén unha tendencia ao seu incremento polo menos desde os comezos do século XXI. En Portugal (Ferreira-Leite et al. 2013), nunha análise dos grandes incendios do período 2003-2012, contabilizáronse 14 que se definen como megaincendios por superaren as 10000 ha, frecuencia aquela que era moi superior á detectada nas décadas dos oitenta e noventa do pasado século. En Galicia, os definidos como grandes incendios (maiores de 500 ha) experimentan, así mesmo, unha progresión crecente, de tal 
xeito que representan o 10,6 \% no período 1991-2000, o 27,8 \% no 2001-2010 e o 38,2 \% no 2011-2017. Neste último ano produciuse tamén o primeiro megaincendio (>10000 ha) da comunidade.

As causas ás que se atribúe esta presenza crecente dos megaincendios céntranse primeiramente no cambio climático, que, segundo todas as análises, leva a un incremento do risco de incendios - de resultas, sobre todo, do aumento da temperatura- e, para determinadas zonas, como son as de clima mediterráneo, a unha previsible tendencia cara a unhas maiores secas. De acordo coas ditas análises, estes cambios supoñen unhas condicións máis favorables para as combustións intensas, xunto cunha ampliación do período anual de risco de incendios, ao que se suma a presenza de combustibles cada vez máis secos e inflamables.

Por outra parte, tamén se ponderou a influencia dun maior amoreamento de biomasa combustible, inicialmente provocado por causas socioeconómicas como as consideradas para o espazo galego-portugués, pero tampouco se descartan outras relacionadas coa dinámica da vexetación despois das queimas, que poderían dar orixe ao carácter cíclico que algúns autores (Bermudez et al. 2009) lles atribúen a tales megafogos.

E, como outra característica destes grandes incendios, sinálase a dos danos, cada vez máis importantes e frecuentes, a propiedades e persoas por mor da ampliación, nos últimos tempos, da interface urbano-forestal (IUF). Esta singularidade, consecuencia dun urbanismo mal planificado, leva a que nos operativos de extinción os obxectivos deriven cada vez máis cara á protección, en primeiro lugar, de edificacións e persoas, deixando como tarefas secundarias os clásicos labores de contención do lume forestal.

As cuestións expostas lévannos á pregunta fundamental que xa formulan moitos expertos: estamos diante dunha nova xeración de lumes? Bowman et al. (2011), no estudo que nos serviu de marco conceptual para este traballo, consideran que estamos entrando xa na fase pírica E, cuxas características definitorias son o cambio climático e as modificacións sobre o combustible, e os españois Castellnou e Miralles (2009), no seu esquema de caracterización dos grandes incendios, sitúannos na quinta xeración de incendios, que comezan co século XXI e se distinguen pola súa incidencia sobre a IUF e a aparición dos megaincendios, sen se descartar a posibilidade dunha sexta xeración, que podería xa estar a empezar, como consecuencia, principalmente, do cambio climático, e 
que se manifestaría por unha ampliación do período de risco de incendios e unha maior frecuencia de aparición de fogos incontrolables.

En calquera caso, son unhas expectativas que, analizadas desde a perspectiva histórica que acabamos de utilizar e, sobre todo, coas proxeccións de futuro coas que necesariamente temos que traballar, deberían merecer a nosa maior atención e preocupación. 


\section{REFERENCIAS BIBLIOGRÁFICAS}

ARESES VidAL, Rafael (1929): Los incendios en los montes públicos, Pontevedra, impr. de E. Paredes Valdés. Bauer Manderscheid, Erich (1980): Los montes de España en la Historia, Madrid, Ministerio de Agricultura.

BEIRAS, José Manuel (1967): El problema del desarrollo en la Galicia rural, Vigo, Galaxia.

Bermudez, P. de Zea / J. Mendes / J. M. C. Pereira / K. F. Turkman / M. J. P. Vasconcelos (2009): «Spatial ann temporal extremes of wildfires in Portugal (1984-2004)», International Journal of Wildland Fire, 18, 983-991.

Boserup, Ester (1967): Las condiciones del desarrollo en la agricultura, Madrid, Tecnos.

BOUHIER, Abel (1979): La Galice : essai géographique d'analyse et d'interprétation d'un vieux complexe agraire, tese de doutoramento, Poitiers, Université de Poitiers.

Bowman, David M. J. S. / Jennifer Balch / Paulo ArtaXo / William J. Bond / Mark A. Cochrane / Carla M. D’Antonio / Ruth DeFries / Fay H. Johnston / Jon E. Keeley / Meg A. Krawchuk / Christian A. Kull / Michelle Mack / Max A. Moritz / Stephen Pyne / Christopher I. Roos / Andrew C. SCOTT / Navjot S. SodHI / Thomas W. SWETNAM (2011): «The human dimension of fire regimes on Earth", Journal of Biogeography, 38, 2223-2236.

Carrión Marco, Yolanda (2005): La vegetación mediterránea y atlántica de la Península Ibérica. Nuevas secuencias antracológicas, Valencia, Diputación de Valencia. (Serie de Trabajos Varios; 104).

Casals Costa, Vicente (1988): «Defensa y ordenación del bosque en España. Ciencia, Naturaleza y Sociedad en la obra de los Ingenieros de Montes durante el siglo XIX», Geocrítica, 73, 3-63.

CaSARIego Fernández, Jesús Evaristo (1950): El Marqués de Sargadelos: los comienzos del industrialismo capitalista en España, Oviedo, Real Instituto de Estudios Asturianos.

Castellnou, Marc / Edgar NeBot / Marta Miralles (2007): «El papel del fuego en la gestión del paisaje», IV International Wildfire Conference, Seville, Spain.

Castellnou i Ribau, Marc / Marta Miralles Bover (2009): «The changing face of wildfires», Crisis Response Journal, 5:4, 56-57.

Connor, Simon E. / João Araujo / Willen O. van der KnaAp / Jacqueline F. N. van Leeuwen (2012): "A long-term perspective on biomass burning in the Serra da Estrela, Portugal», Quaternary Science Reviews, 55, 114-124.

DEVY-VARETA, Nicole (1999): «Investigación sobre la Historia Forestal portuguesa en los siglos XIX y XX: orientaciones y lagunas", Historia Agraria, 18, 57-94.

Díaz-Fierros Viqueira, Francisco (2006): A cuestión ambiental en Galicia: raíces dunha nova cultura (1750-1972), Vigo, Galaxia.

Fábregas Valcarce, Ramón / Carlos Fernández Rodríguez / Pablo Ramil Rego (1997): «La adopción de la economía productora en el Noroeste ibérico», en Antón A. Rodríguez Casal (ed.), O Neolítico atlántico e as orixes do megalitismo, Santiago de Compostela, Universidade / Consello da Cultura Galega, 463-484.

Ferreira-Leite, Flora / Luciano Lourenço / António Bento-GonÇALVES (2013): «Large forest fires in mainland Portugal, brief characterization», Méditerranée: Revue géographique des pays méditerranéens, $121,53-65$.

Ferreira Rodrigues, Teresa (coord.) (2008): História da População Portuguesa: das longas permanências à conquista da modernidade, Porto, Afrontamento. 
Fontana TarRats, José María (1977): Historia del clima del Finis-Terrae Gallego, Madrid, ed. fotocopiada. Guitián RIVERA, Luis (1999): «Los incendios forestales a través de la historia: pervivencias y cambios en el uso del fuego en el noroeste peninsular», en Eduardo Araque Jiménez (coord.), Incendios históricos: una aproximación multidisciplinar, Baeza, Universidad Internacional de Andalucía.

GuyetTe, Richard P. / Michael C. Stambaugh / Daniel C. Dey / Rose-Marie MuZIKA (2012): «Predicting fire frequency with chemistry and climate», Ecosystems, 15, 322-335.

Heyck-Williams, Shannon / Lauren Anderson / Bruce A. Stein (2017): Megafires: The Growing Risk to America's Forests, Communities, and Wildlife, Washington, D.C., National Wildlife Federation.

IBÁÑEZ, Antonio Raymundo, marqués de Sargadelos (2009): Discursos económico-políticos sobre la restauración de los montes y plantios en España (1802), ed. de Joaquín Ocampo Suárez-Valdés, Oviedo, Real Instituto de Estudios Asturianos / Xunta de Galicia.

IVERSEN, Johannes (1956): «Forest Clearance in the Stone Age», Scientific American, 194:3, 36-41.

Koutsias, Nikos / Britta AllgöWer / Kostas Kalabokidis / Giorgos Manillis / Panagiotis Balatsos / Johann G. Goldammer (2015): «Fire occurrence zoning from local to global scale in the European Mediterranean basin: implications for multi-scale fire management and policy», iForest. Biogeosciences and Forestry, 9, 195-204.

Lobo Alves, António (coord.) (2003): O Abandono da Actividade Agrícola, Lisboa, Ministério da Agricultura, do Desenvolvimento Rural e das Pescas / Ministério do Ambiente e do Ordenamento do Território.

Martínez-Cortizas, Antonio / Manuela Costa-Casais (2016): «A paisaxe: síntese da historia ambiental e cultural», en Felipe Criado Boado / César Parcero Oubiña / Carlos Otero Vilariño / Elena Cabrejas (eds.), Atlas arqueolóxico da paisaxe galega, Vigo, Xerais.

Molina RodríGuez, Fernando (1979): «Producción e ecoloxía no monte galego», Revista Galega de Estudios Agrarios, 2, 33-56.

Monteiro Alves, António A. / Nicole Devy-Vareta / Ângelo C. Oliveira / João S. Pereira (2006): «A floresta e o fogo através dos tempos», en João Santos Pereira / José Miguel Cardoso Pereira / Francisco Castro Rego / João M. Neves Silva / Tiago Pereira da Silva (coords.), Incêndios Florestais em Portugal: Caracterizacão, Impactes e Prevencão, Lisboa, Instituto Superior de Agronomia, 15-40.

Pausas, Juli G. / Jon E. Keeley (2009): "A Burning Story: The Role of Fire in the History of Life», BioScience, 59, 593-601.

PeChony, Olga / Drew T. SHindell (2010): «Driving forces of global wildfires over the past millennium and the forthcoming century», PNAS, 107:45, 19167-19170.

PYNE, Stephen J. (1997): Vestal Fire: An Environmental History, Told through Fire, of Europe and Europe's Encounter with the World, Seattle / London, University of Washington Press.

Ramil-Rego, Pablo / María Jesús Aira Rodríguez / María Teresa Taboada Castro (1994): «Análisis polínico y sedimentológico de dos turberas en las Sierras Septentrionales de Galicia (N.O. de España)», Revue de Paléobiologie, 13:1, 9-28.

Ruiz Zorrilla, Pedro (1980): «Notas para una historia del pino en Galicia», en Olga Gallego Domínguez / Pedro López Gómez / Pablo Taboada Moure / Antonio Rigueiro Rodríguez (coords.), El monte en Galicia: fuentes para su estudio, Madrid, Ministerio de Cultura.

VélEZ MuÑoz, Ricardo (2015): «Breve (e incompleta) historia de las aportaciones técnicas de los Ingenieros de Montes contra incendios forestales en los pasados 60 años», presentación en PowerPoint (14 de marzo).

Villares PaZ, Ramón (coord.) (1980): Historia de Galiza, Madrid, Alhambra / Caixa de Aforros de Galicia. 